\title{
Diel periodicity of nitrogen and carbon assimilation in five species of marine phytoplankton: accuracy of methodology for predicting $\mathbf{N}$-assimilation rates and $\mathrm{N} / \mathrm{C}$ composition ratios*
}

\author{
Giacomo R. DiTullio \& Edward A. Laws \\ University of Hawaii, Department of Oceanography, 1000 Pope Road, Honolulu, Hawaii 96822, USA \\ and \\ Hawaii Institute of Marine Biology, Coconut Island, P.O. Box 1346, Kaneohe, Hawaii 96744, USA
}

\begin{abstract}
Diel patterns of carbon and nitrogen assimilation were investigated in 5 taxonomically diverse species of unicellular algae grown in $\mathrm{NH}_{4}^{+}$-limited cyclostats $(12: 12 \mathrm{~L}$ :D). Calculated $24 \mathrm{~h}$ average rates of $\mathrm{N}$-assimilation based on $\mathrm{C}-14$ incorporation into protein overestimated the actual rate by an average of $24 \pm 27 \%$. Overestimation of carbon assimilation by the C-14 method (16 $\pm 19 \%)$ accounted for most of the observed discrepancy in the estimation of $\mathrm{N}$-assimilation rates. Estimates of actual $\mathrm{N}$-assimilation rates were more accurate at high relative growth rates (104 $\pm 20 \%)$ than at low relative growth rates $(143 \pm 22 \%)$. The $\mathrm{N} / \mathrm{C}$ assimilation ratio provided an accurate estimate $(104 \pm$ $16 \%$ ) of the $\mathrm{N} / \mathrm{C}$ composition ratio after a $12: 12 \mathrm{~L}: \mathrm{D}$ cycle. The percentage decrease in particulate C-14 activity at night due to respiration was $105 \%$ greater than the predicted decrease estimated from the loss in particulate carbon concentration. Dark respiration of carbon with an average specific activity equal to that of the inorganic carbon could not entirely account for this phenomenon. Excretion of dissolved organic carbon (DOC) during the photoperiod and uptake of low specific activity DOC at night may have been responsible for the decrease in specific activity of particulate C-14 at night.
\end{abstract}

\section{INTRODUCTION}

Since phytoplankton cells are continuously adapting to changes in environmental conditions, tracing the recent end-products of photosynthesis (Morris et al. 1974) can reveal valuable information about how cells interact with their environment (e.g. Barlow 1984). The chemical composition of a phytoplankton population is a manifestation of its current physiological state (Caperon \& Meyer 1972, Perry 1976, Sakshaug \& Holm-Hansen 1977, Goldman et al. 1979). Chemical composition ratios such as $\mathrm{Chl} / \mathrm{C}, \mathrm{P} / \mathrm{C}$ and $\mathrm{N} / \mathrm{C}$ have been previously examined in order to gauge their accuracy in predicting relative growth rates of phytoplankton populations (Goldman 1980). However, direct measurement of the intracellular composition

\footnotetext{
- Hawaii Institute of Marine Biology Contribution No. 722
}

ratio in nature is biased due to the presence of detritus. Glibert et al. (1985) for example argue that phytoplankton accounted for only $7 \%$ of the particulate nitrogen at stations they studied in the Sargasso Sea. As a consequence an indirect approach must be adopted. One such approach is to estimate the N/C composition ratio from the $\mathrm{N} / \mathrm{C}$ assimilation ratio.

However, N/C assimilation ratios as measured by ${ }^{14} \mathrm{C}$ and ${ }^{15} \mathrm{~N}$ reported for natural populations have varied considerably (MacIsaac \& Dugdale 1972, Eppley et al. 1973, Slawyk et al. 1978). Although several factors are probably responsible, one of the main causes of concern has been the validity of ${ }^{15} \mathrm{~N}$ tracer estimates of $\mathrm{N}$-assimilation rates in oligotrophic oceans (Harrison 1983). As an alternative, $\mathrm{N}$-assimilation rates can be determined in oligotrophic $\mathrm{N}$-limited systems by monitoring the incorporation of ${ }^{14} \mathrm{CO}_{2}$ into protein (DiTullio \& Laws 1983). Two critical but as yet untested 
assumptions in the application of this method are: (1) that C-14 incorporated into protein is directly correlated with the actual $\mathrm{N}$-assimilation rate during all portions of the growth cycle, and (2) that the N/C assimilation ratio is an accurate estimate of the $\mathrm{N} / \mathrm{C}$ composition ratio at some point of the diel cycle. The present study was undertaken in order to investigate these potential problems. Steady-state $\mathrm{NH}_{4}^{+}$-limited cultures of 5 species of marine phytoplankton were grown in order to investigate the effects of the lightdark cycle on carbon and nitrogen assimilation patterns.

\section{MATERIALS AND METHODS}

$\mathrm{NH}_{4}^{+}$-limited continuous cultures of phytoplankton representing 5 taxonomic classes of algae were grown in cyclostats similar to those described by Laws \& Bannister (1980). The unicellular species investigated in this study included: Phaeodactylum tricornutum (Bacilliarophyta), Pavlova lutheri (Prymnesiophyta), Dunaliella salina (Chlorophyta), Isochrysis sp. (Tahitian clone) (Chrysophyta) and Amphidinium carteri (Pyrrophyta). The cultures of $P$. tricornutum, $P$. lutheri and $A$. carteri were obtained from the Food Chain Research Group Culture Collection at the Scripps Institution of Oceanography. The cultures of $D$. salina and Isochrysis sp. were obtained from Aquacorp (Tahiti)

Relatively low (27 to $38 \%$ of $\mu_{m}$ ) and high $(62$ to $93 \%$ of $\mu_{m}$ ) growth rate experiments were performed with each species. A 51 reaction vessel was used for the low dilution rate experiments and a 31 vessel for the high dilution rates in order to minimize the potential for perturbation to the steady state caused by sampling. Samples were taken at $6 \mathrm{~h}$ intervals. The input medium pump was left on for the duration of the experiment. The total volume withdrawn from the growth chamber after sampling at each time point never exceeded the $6 \mathrm{~h}$ pumping rate volume and was always less than $6.2 \%$ of the growth chamber volume. During the time that the growth chamber is refilling following withdrawal of a small sample, the mathematical equations governing the rate of change of substances in the growth chamber are virtually identical to those describing overflow conditions, because the increase in culture volume due to the input of fresh medium dilutes the culture in a manner similar to that resulting from overflow under constant volume conditions (Laws 1985). Hence, it is assumed that sampling did not significantly perturb the steady-state condition of the phytoplankton population.

Nutrient-poor seawater was collected from an oligotrophic station approximately $1.5 \mathrm{~km}$ outside of Kaneohe Bay, Hawaii. This water served as the growth medium after enrichment with $50 \mu \mathrm{M} \mathrm{NH}+4,50 \mu \mathrm{M}$ $\mathrm{PO}_{4}^{3-}$, IMR vitamins (Eppley et al. 1967) and f/2 metals (Guillard \& Ryther 1962) followed by sterile filtration $\left(0.22 \mu \mathrm{m}_{i}\right.$ Gelman). Steady state at a given dilution rate was assumed when cell counts on a particle counter (Celloscope) were constant to within $\pm 5 \%$ for a minimum of 3 consecutive $\mathrm{d}$.

Temperature in the growth chamber was held constant by water circulating through the outside jacket of the double-walled reaction flask. Experiments with Pavlova lutheri and Phaeodactylum tricornutum were conducted at $16.5^{\circ} \mathrm{C}$. Cyclostats of Amphidinium carteri and Isochrysis sp. were maintained at $25.5^{\circ} \mathrm{C}$; Dunaliella salina was grown at $21^{\circ} \mathrm{C}$. Our previous experience with these species had shown that these temperatures permitted vigorous growth of each of the 5 species.

Light was supplied by a bank of 8 vita-lite $(40 \mathrm{~W})$ fluorescent lamps set on a $12 \mathrm{~h}$ light and $12 \mathrm{~h}$ dark cycle. Growth chamber irradiance measured at the

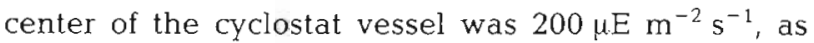
measured with a Biospherical Instruments Corporation QSI-100 quantum scalar irradiance meter.

The cyclostat was inoculated at the beginning of the photoperiod with $200 \mu \mathrm{Ci} \mathrm{NaH}{ }^{14} \mathrm{CO}_{3}$ (specific activity $=56 \mathrm{mCi} \mathrm{mmol}^{-1}$ ) to yield a final activity of 50 to 70 $\mu \mathrm{Ci} l^{-1}$ depending on the size of the reaction vessel. Samples were taken $1 \mathrm{~min}$ after inoculation, as well as 6, 12, 18 and 24 h later. Triplicate $10 \mathrm{ml}$ samples were filtered onto Whatman GF/C glass fiber filters and partitioned by solvent extraction. The various macromolecular fractions (lipid, polysaccharide, protein, and low molecular weight intermediates) were then assayed for radioactivity by adding $10 \mathrm{ml}$ of ACS cocktail (Amersham) and counted on a Searle 100 scintillation counter. Samples were corrected for quench by the external standards ratio method. Cell fractionations were performed using the methods outlined in DiTullio \& Laws (1983) with 2 notable exceptions. (1) Filters were not stored in a $\mathrm{CHCl}_{3}: \mathrm{MeOH}$ mixture directly but rather were stored frozen $\left(-20^{\circ} \mathrm{C}\right)$ since $\mathrm{CHCl}_{3}$ can destroy the quaternary structure in protein by breaking down the hydrophobic interactions of the amino acids. This breakdown can affect the efficiency of the subsequent lipid extraction ( $T$. Tornabene pers. comm.). (2) The filters were extracted in $5 \%$ TCA at $85^{\circ} \mathrm{C}$ instead of $100^{\circ} \mathrm{C}$, since at temperatures above $90^{\circ} \mathrm{C}$ there may be a release of acid-soluble peptides in $5 \%$ TCA (Marchesi \& Kennell 1967).

Members of the Chlorophyta and Cyanophyta phyla have cell walls that are harder to disrupt than other classes of algae. As a result cell fractionations of Dunaliella salina were performed using the Bligh \& Dyer (1959) lipid extraction as outlined in Li et al. (1980). The major difference (aside from the final 
$\mathrm{CHCl}_{3}: \mathrm{MeOH}$ ratio) between the Bligh \& Dyer (1959) and the Folch et al. (1957) extraction is the addition of water in the Bligh \& Dyer scheme. This addition presumably facilitates the penetration and disruption of the tougher cell walls of these algal groups

Triplicate $50 \mathrm{ml}$ samples were withdrawn from the growth chamber at the sampling times mentioned above for the measurement of particulate carbon (PC) and particulate nitrogen (PN). Samples were filtered onto precombusted $\left(450^{\circ} \mathrm{C}, 24 \mathrm{~h}\right.$ ) Whatman GF/C glass fiber filters, stored frozen at $-20^{\circ} \mathrm{C}$ and analyzed on a CHN elemental analyzer (Hewlett-Packard Model 185B) using cyclohexanone 2,4-dinitrophenylhydrazone as the calibration standard.

Triplicate $1 \mathrm{ml}$ samples were placed in $0.5 \mathrm{ml}$ of a $1: 1$ solution of 2 -methoxy-ethylamine: $\mathrm{H}_{2} \mathrm{O}$ to trap the inorganic C-14 activity. Duplicate $5 \mathrm{ml}$ samples were taken for total particulate ${ }^{14} \mathrm{C}$ incorporation. The activities in these samples were used as a check to ensure that the sum of the fractions (lipids, polysaccharides + nucleic acids, intermediates, and proteins) were approximately equal to the sum of the non-fractionated total particulate ${ }^{14} \mathrm{C}$ activity. The sum of the fractions in this study averaged $2 \%$ greater than the total particulate ${ }^{14} \mathrm{C}$ activity.

Dissolved inorganic carbon concentrations were measured by the methods outlined in Strickland \& Parsons (1968). The total $\mathrm{CO}_{2}$ concentration was found to be at a minimum at the end of the photoperiod $(\sim 1.8 \mathrm{mM})$ and at a maximum at the beginning of the photoperiod $(\sim 1.9 \mathrm{mM})$. The average was used for all calculations.

Estimated 24 h average rates of $\mathrm{C}$ and $\mathrm{N}$ assimilation were determined by averaging the rates obtained at the $6,12,18$, and 24 h time points. The rate of actual $\mathrm{C}$ and $\mathrm{N}$ assimilation were obtained by measuring the particulate $\mathrm{C}$ and $\mathrm{N}$ in the growth chamber and then applying Eqn (16) in Laws (1985). The accuracy of estimating $\mathrm{N}$-assimilation rates and $\mathrm{N} / \mathrm{C}$ composition ratios were determined by dividing the estimated rates by the actual values measured by CHN analyses.

The rate of incorporation of ${ }^{14} \mathrm{C}$ activity into the particulate fraction ( $p$ ) over a given time interval at a specific dilution rate $(\mu)$ was calculated using the equation

$$
\frac{\mathrm{df}}{\mathrm{dt}}=\mathrm{p}-\mu \mathrm{f}
$$

where $\mathrm{f}=$ activity in the particulate carbon. Integrating this equation and rearranging to solve for $\mathrm{p}$ yields

$$
p=\mu\left(f_{t} e^{\mu t}-f_{0}\right) /\left(e^{\mu t}-1\right)
$$

where $\mathrm{f}_{0}=\mathrm{dpm}$ in the particulate fraction at the start of the time interval; $\mathrm{f}_{\mathrm{t}}=\mathrm{dpm}$ at time $\mathrm{t}$. This equation corrects for dilution in the growth chamber due to the input of fresh medium. The protein production rate (from ${ }^{14} \mathrm{C}$ protein labeling kinetics) was calculated similarly by substituting the dpm in the protein fraction for $\mathrm{f}$ in Eqn 2.

Nitrogen assimilation rates were calculated from total ${ }^{14} \mathrm{C}$ uptake and the percentage of ${ }^{14} \mathrm{C}$ incorporated into the protein fraction by assuming that protein $\mathrm{N}$ accounted for $85 \%$ of cellular $\mathrm{N}$ with protein having an N/C ratio of 0.30 by weight (DiTullio \& Laws 1983).

\section{RESULTS}

Calculated $\mathrm{N}$-assimilation rates were overestimated (relative to the actual $\mathrm{N}$-uptake rate) more at the lower growth rates than at the higher growth rates both at the end of the photoperiod (e.g. Fig. 1) and at the end of $24 \mathrm{~h}$ (Table 1) for all species studied. In addition to a growth rate effect on the calculated $\mathrm{N}$-assimilation rate, there was also a significant difference between the light and dark period average for $\mathrm{N}$-assimilation rates over all growth rates (Table 2). $\mathrm{N}$-assimilation rates were overestimated during the photoperiod by an average $( \pm \mathrm{SD}$ ) of $71 \pm 57 \%$ for all species. The dark $\mathrm{N}$-assimilation rate was actually underestimated by an average of $24 \pm 24 \%$ (Table 2). Although the trend of overestimation during the photoperiod and underestimation in the dark was similar for all species tested, the variation in the magnitude of the estimated $\mathrm{N}$ assimilation rates among species was very pronounced (Table 2).

The percentage of ${ }^{14} \mathrm{C}$ incorporated into protein was

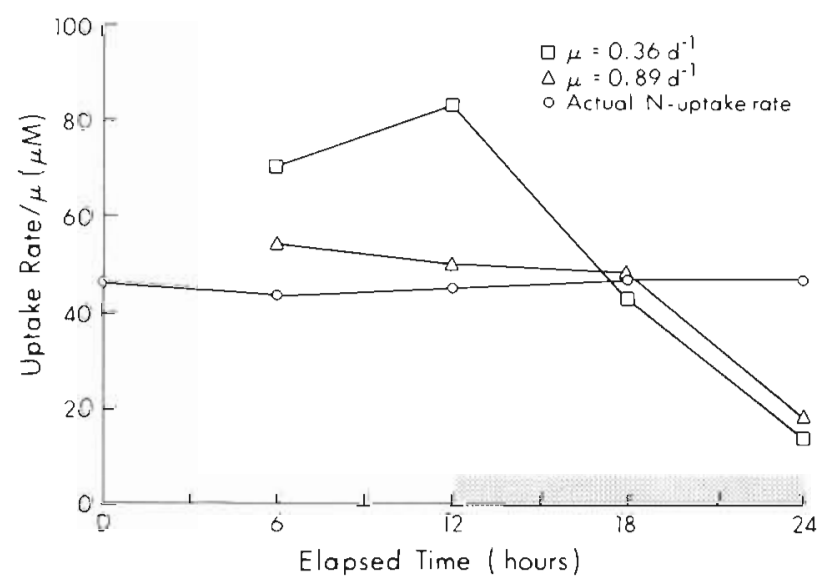

Fig. 1. Dunaliella salina. Comparison of actual and estimated $\mathrm{N}$-assimilation rates during light-dark cycle when grown at dilution rates of 0.36 and $0.89 \mathrm{~d}^{-1}$. Rates $\left(\mu \mathrm{M} \mathrm{d}^{-1}\right)$ have been divided by $\mu\left(\mathrm{d}^{-1}\right)$ to facilitate presentation on the same graph. Estimated $\mathrm{N}$-assimilation rates were calculated from ${ }^{14} \mathrm{C}$ incorporation rate into protein assuming that $85 \%$ of cellular $\mathrm{N}$ is found in the form of protein with an $\mathrm{N} / \mathrm{C}$ ratio of 0.3 by weight 
Table 1 Carbon and nitrogen assimilation rates calculated from ${ }^{14} \mathrm{C}$ incorporation into particulate and protein $\mathrm{C}$ averaged over the $24 \mathrm{~h}$ Light-dark cycle. Calculated rates are expressed as percentages of the actual particulate $\mathrm{C}$ and $\mathrm{N}$ assimilation rates as determined by CHN elemental analyses and use of Eqn (16) in Laws (1985)

\begin{tabular}{|c|c|c|c|c|}
\hline Species & $\mu\left(\mathrm{d}^{-1}\right)$ & $\%$ C-assimilation & $\% \mathrm{~N}$-assimilation & $\% \mathrm{~N} / \mathrm{C}^{\circ}$ \\
\hline P. tricornutum & $\begin{array}{l}0.56 \\
0.25\end{array}$ & $\begin{array}{r}87 \\
144\end{array}$ & $\begin{array}{r}88 \\
142\end{array}$ & $\begin{array}{r}100 \\
95\end{array}$ \\
\hline P. lutheri & $\begin{array}{l}0.75 \\
0.29\end{array}$ & $\begin{array}{l}101 \\
126\end{array}$ & $\begin{array}{r}88 \\
134\end{array}$ & $\begin{array}{r}92 \\
100\end{array}$ \\
\hline Isochrysis $\mathrm{sp}$. & $\begin{array}{l}0.93 \\
0.40\end{array}$ & $\begin{array}{l}114 \\
113\end{array}$ & $\begin{array}{l}124 \\
161\end{array}$ & $\begin{array}{l}105 \\
144\end{array}$ \\
\hline A. carteri & $\begin{array}{l}0.48 \\
0.20\end{array}$ & $\begin{array}{l}132 \\
139\end{array}$ & $\begin{array}{l}126 \\
159\end{array}$ & $\begin{array}{r}87 \\
115\end{array}$ \\
\hline D. salina & $\begin{array}{l}0.89 \\
0.36\end{array}$ & $\begin{array}{r}98 \\
104\end{array}$ & $\begin{array}{r}94 \\
116\end{array}$ & $\begin{array}{r}94 \\
104\end{array}$ \\
\hline Average $\pm S D$ & & $116 \pm 19$ & $124 \pm 27$ & $104 \pm 16$ \\
\hline $\begin{array}{l}\text { P. tricornutum } \\
\text { cont. light }\end{array}$ & $\begin{array}{l}0.53 \\
0.23\end{array}$ & $\begin{array}{l}102 \\
100\end{array}$ & $\begin{array}{l}101 \\
115\end{array}$ & $\begin{array}{r}99 \\
119\end{array}$ \\
\hline
\end{tabular}

Table 2. Calculated rates of $\mathrm{N}$-assimilation based on $\mathrm{C}-14$ incorporation into protein. Values are expressed as percentages of the actual rates as determined by CHN elemental analyses, and use of Eqn (16) in Laws (1985)

\begin{tabular}{|c|c|c|c|c|}
\hline Species & $\mu\left(d^{-1}\right)$ & $12 \mathrm{~h} \mathrm{light}$ & $12 \mathrm{~h} \mathrm{dark}$ & $24 \mathrm{~h}$ average \\
\hline P. tricornutum & $\begin{array}{l}0.56 \\
0.25\end{array}$ & $\begin{array}{l}101 \\
178\end{array}$ & $\begin{array}{r}74 \\
106\end{array}$ & $\begin{array}{r}88 \\
142\end{array}$ \\
\hline P. Iutheri & $\begin{array}{l}0.75 \\
0.29\end{array}$ & $\begin{array}{r}98 \\
176\end{array}$ & $\begin{array}{l}79 \\
93\end{array}$ & $\begin{array}{r}88 \\
135\end{array}$ \\
\hline Isochrysis sp. & $\begin{array}{l}0.93 \\
0.40\end{array}$ & $\begin{array}{l}154 \\
219\end{array}$ & $\begin{array}{r}95 \\
104\end{array}$ & $\begin{array}{l}124 \\
161\end{array}$ \\
\hline A. carteri & $\begin{array}{l}0.48 \\
0.20\end{array}$ & $\begin{array}{l}213 \\
278\end{array}$ & $\begin{array}{l}40 \\
41\end{array}$ & $\begin{array}{l}126 \\
160\end{array}$ \\
\hline D. salina & $\begin{array}{l}0.89 \\
0.36\end{array}$ & $\begin{array}{l}119 \\
172\end{array}$ & $\begin{array}{l}70 \\
60\end{array}$ & $\begin{array}{r}94 \\
116\end{array}$ \\
\hline $\begin{array}{l}\text { Low growth rates } \\
\text { High growth rates } \\
\text { All growth rates }\end{array}$ & & $\begin{array}{l}205 \pm 46 \\
137 \pm 48 \\
171 \pm 57\end{array}$ & $\begin{array}{l}81 \pm 29 \\
72 \pm 20 \\
76 \pm 24\end{array}$ & $\begin{array}{l}143 \pm 20 \\
104 \pm 20 \\
124 \pm 27\end{array}$ \\
\hline - Average $\pm \mathrm{SD}$ & & & & \\
\hline
\end{tabular}

ncarly identical at the 6 and 12 h time points (Fig. 2). The average difference between the $6 \mathrm{~h}$ and $12 \mathrm{~h}$ percent protein values for all species was $1.1 \pm 0.7 \%$. Night-time protein synthesis measured at the 18 and $24 \mathrm{~h}$ time points resulted in an average increase in percent protein over the average photoperiod value by a factor of $1.6 \pm 0.65$ and $2.13 \pm 0.35$ respectively for all species tested. Due to respiration at night of recently assimilated products (mostly from the polysaccharide pool), as well as continued protein synthesis (albeit at a lower rate than light protein synthesis), the percent protein approximately doubled in value during the dark period, although the actual protein pro- duction rate decreased slightly at night relative to the light protein synthesis rate.

Macromolecular production rates were calculated by assuming that the precursor $\mathrm{C}$ specific activity was equal to the average inorganic carbon (IOC) specific activity during the photoperiod. In general, all species synthesized polysaccharides during the day and catabolized them at night (Fig. 2). Lipids and LMW intermediates were synthesized during the light period, but there was no net synthesis of these compounds at night (Fig. 2).

The $\mathrm{N} / \mathrm{C}$ assimilation ratio was constant during the photoperiod, but was consistently less than the $\mathrm{N} / \mathrm{C}$ 
composition ratio (Fig. 3). The average difference for all species between the $\mathrm{N} / \mathrm{C}$ assimilation ratio and the $\mathrm{N} / \mathrm{C}$ composition ratio decreased during the first $6 \mathrm{~h}$ of darkness by an average of $54.8 \pm 9.6 \%$. During the final $6 \mathrm{~h}$, the $\mathrm{N} / \mathrm{C}$ assimilation ratio increased by an average of $47.4 \pm 21.2 \%$. The result is that the protein labeling method yields the most accurate estimate of the $\mathrm{N} / \mathrm{C}$ composition ratio at the end of a light-dark incubation (Fig. 3). At the $24 \mathrm{~h}$ time point (end of the dark period), the $\mathrm{N} / \mathrm{C}$ assimilation ratio averaged 103.8 $\pm 16.5 \%$ of the $\mathrm{N} / \mathrm{C}$ composition ratio for the 5 species tested (Table 1).

Although the $\mathrm{N}$-assimilation rate was overestimated, the $\mathrm{N} / \mathrm{C}$ assimilation ratio nonetheless provided an accurate prediction of the $\mathrm{N} / \mathrm{C}$ composition ratio after $24 \mathrm{~h}$. The implication from these results is that the overestimation in $\mathrm{N}$-assimilation must have been pro-

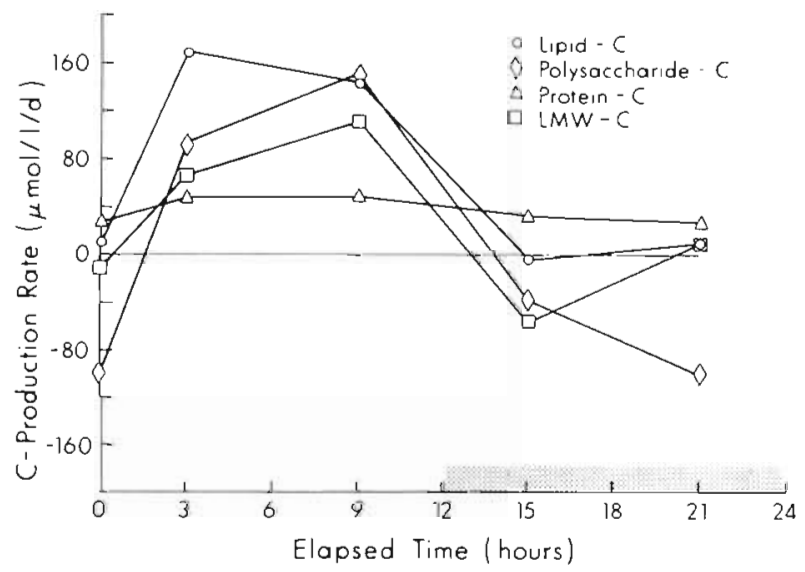

Fig. 2. Phaeodactylum tricornutum. Diel patterns of production rate of $\mathrm{C}-14$ labeled macromolecules growing at $0.25 \mathrm{~d}^{-1}$ The rates between 2 successive time points were averaged and plotted at the mean of the sampling time

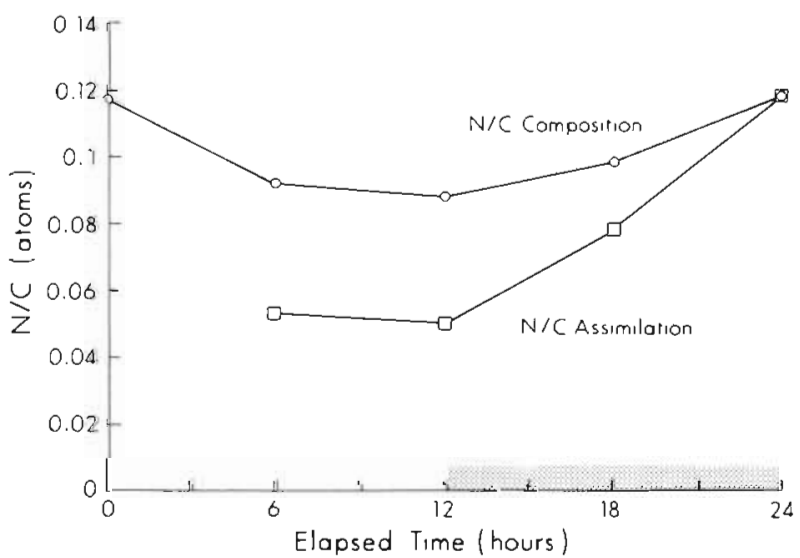

Fig. 3. Phaeodactylum tricornutum. Relation between N/C assimilation ratio (calculated from $\mathrm{C}-14$ incorporation into protein and total particulate $\mathrm{C}$ ) and $\mathrm{N} / \mathrm{C}$ composition ratio (calculated from elemental analysis) during diel cycle when growing at $0.56 \mathrm{~d}^{-1}$ duced in part by an overestimation in net particulate carbon production, since $\mathrm{N}$-assimilation is calculated from carbon assimilation into protein.

Rates of particulate carbon production estimated using the traditional C-14 method were therefore compared to the actual rates of PC production in the growth vessel (Table 1). The latter rates were calculated using Eqn (16) of Laws (1985).

During the photoperiod, the average $C$ production rate (average of the 6 and $12 \mathrm{~h}$ values calculated from Eqn [2]) based on C-14 uptake was $24 \pm 25 \%$ higher than the actual PC production rate. The decrease in particulate $\mathrm{C}-14$ activity at night due to respiration was greater than the predicted decrease estimated from the loss of particulate $\mathrm{C}$ by an average of $105 \pm 104 \%$. The $24 \mathrm{~h}$ average production rate for all species based on $\mathrm{C}-14$ uptake was $116 \pm 19 \%$ of the particulate carbon production rate (Table 1). A trend of higher overestimation at lower growth rates $(126 \pm 17 \%)$ than higher growth rates $(107 \pm 18 \%)$ was found for PC production. This trend was similar to the pattern found in $\mathrm{N}$-assimilation rates (Table 1).

The percentage of ${ }^{14} \mathrm{C}$ allocated to protein under $\mathrm{N}$ limitation varies almost linearly as a function of the relative growth rate of a population (e.g. Redalje 1980). Even if cells are not actively growing (i.e. $\mu=0$ ) their cellular protein structure will represent a finite percentage of the total cellular carbon. Based on a regression analysis of results from the 5 species tested in this study, the average minimum and maximum percent cell protein are 15 and $46 \%$ at relative growth rates of 0 and 1 , respectively. Although only one high and one low growth rate were studied using cyclostats, the observed \% protein measured after a $24 \mathrm{~h}{ }^{14} \mathrm{C}$ incubation in exponentially growing batch cultures was $93 \%$ of the value predicted from a line drawn through the 2 data points for each species (Table 3 ).

\section{DISCUSSION}

The overestimation of both $\mathrm{N}$-assimilation and $\mathrm{C}$ assimilation during the photoperiod (Table 2) reflects the fact that the rate of protein synthesis is directly coupled to photosynthetic C production. Similarly, Thacker \& Syrett (1972) demonstrated that $\mathrm{CO}_{2}$ fixation was required before $\mathrm{NH}_{4}^{+}$uptake could proceed in batch cultures of Chlamydomonas sp. grown on a 12: 12 L: D cycle.

Initially, after inoculation with ${ }^{14} \mathrm{CO}_{2}$, the specific activity of the protein carbon is less than the specific activity of the protein precursor C. If protein is turning over, then net protein synthesis rates will be overestimated, and this fact could in part explain the higher estimated rates of $\mathrm{N}$-assimilation found during the 
Table 3 . Comparison of the estimated $\%$ protein and actual \% protein of cells growing at $\mu_{m}$. Estimated values were calculated from a line drawn through the $2 \mathrm{~N}$-limited cyclostat data points for each species. Slope and $y$-intercept of that line are listed for each species

\begin{tabular}{|c|c|c|c|c|c|}
\hline Species & $\mu_{m}\left(d^{-1}\right)^{\circ}$ & Slope & $y$-int. & $\begin{array}{c}\text { Estimated } \% \text { prot. } \\
\text { at } \mu_{m}\end{array}$ & $\begin{array}{l}\text { Observed \% prot. } \\
\text { in batch culture }\end{array}$ \\
\hline P. tricornutum & 0.91 & 42.4 & 12.5 & 54.9 & 47.9 \\
\hline P. luther & 0.81 & 31.6 & 10.6 & 42.2 & 39.6 \\
\hline Isochrysis sp. & 1.20 & 38.5 & 8.2 & 46.7 & 44.5 \\
\hline D. salina & 1.04 & 16.3 & 22.9 & 39.2 & 41.1 \\
\hline A. carteri & 0.52 & 26.0 & 18.9 & 44.9 & 39.1 \\
\hline Average & - & 31.0 & 14.6 & 45.6 & 42.4 \\
\hline
\end{tabular}

photoperiod. However, it seems unlikely that protein turnover is the major cause of the overestimation for a number of reasons. First, the fact that the $\mathrm{N} / \mathrm{C}$ assimilation ratio actually underestimated the $\mathrm{N} / \mathrm{C}$ composition ratio during the photoperiod (Fig. 3) suggests that the discrepancy may be due to a specific activity disequilibrium between the protein $C$ and total $C$ pools. Secondly, protein turnover rates have been reported to be only around 2 to $3 \% \mathrm{~h}^{-1}$ in microbial populations (Pine 1972). However, measurement of this process is no trivial task (Huffaker \& Peterson 1974). In addition, protein turnover may well be an important physiological response of the cell under fluctuating environmental conditions where the synthesis and repression of key enzymes is continuously changing. But in a system such as a cyclostat where environmental conditions are reproducible from one day to the next, it is not clear what the adaptive significance of such a process would be.

Another possible explanation for the overestimation of $\mathrm{N}$-assimilation during the photoperiod is $\mathrm{N}$-pooling at night. The production of protein observed at night (Fig. 2) is consistent with other studies that have also documented this process (Morris et al. 1974, Morris \& Skea 1978, Wheeler et al. 1983, Cuhel et al. 1984, Terry et al. 1985). Since ambient $\mathrm{NH}_{4}^{+}$concentrations in the cyclostat were always found to be $<0.5 \mu \mathrm{M}$ and protein production rates were lower at night than during the photoperiod (Fig. 2) it appears that $\mathrm{N}$ is being stored at night in some form other than protein (e.g. amino acids). At the beginning of the photoperiod, this pool of intracellular $\mathrm{N}$ may allow protein production to proceed at an enhanced rate until the $N$ reserves become depleted.

If the protein production rates during the photoperiod were indeed enhanced because of $\mathrm{N}$ pooling at night, then operating a chemostat population grown under continuous light should eliminate the overestimation in $\mathrm{N}$-assimilation by removing the $\mathrm{N}$-pooling stimulus. Since N-assimilation was still overestimated $(15 \%)$ for Phaeodactylum tricornutum at a low relative growth rate on continuous light (Table 1), it would appear that light/dark cycle effects on protein production are not the sole cause for the overestimation in $\mathrm{N}$ assimilation rates. However, at the high relative growth rate under continuous light, $\mathrm{N}$-assimilation was accurately predicted (Table 1).

The larger overestimation in the $\mathrm{N}$-assimilation rate $(15 \%)$ of Phaeodactylum tricornutum under continuous light at the low growth rate versus the high growth rate $(1 \%)$ is similar to the growth rate effect on $N$ assimilation under a L:D cycle (Table 1). However, when $P$. tricornutum was conditioned on a $12: 12 \mathrm{~L}: \mathrm{D}$ cycle, $N$-assimilation was overestimated (42\%) more so than when the same species was grown under continuous light $(15 \%)$ at a similar low relative growth rate (Table 1). Hence, it appears that the effects of both the $\mathrm{L}: \mathrm{D}$ cycle and growth rate will determine the accuracy of predicting $\mathrm{N}$-assimilation rates from ${ }^{14} \mathrm{CO}_{2}$ incorporation into protein. Faster growth rates and shorter dark periods apparently result in a more accurate estimate of the true $\mathrm{N}$-assimilation rate. Because $\mathrm{N}$-assimilation was overestimated during the photoperiod and underestimated at night, the most accurate estimate of $\mathrm{N}$-assimilation was obtained from the $24 \mathrm{~h}$ average value.

Since $\mathrm{N}$-assimilation rates were estimated from ${ }^{14} \mathrm{CO}_{2}$ incorporation into protein, the overestimation in $\mathrm{N}$-assimilation may have been a direct result of the inherent problems associated with the C-14 method itself. Indeed, overestimation of net particulate carbon (PC) production by the $\mathrm{C}-14$ method accounted for about $2 / 3$ of the overestimation in $\mathrm{N}$-assimilation (Table 1). The most likely cause of the overestimation in net PC production by the C-14 method is due to tracer disequilibrium. Smith (1982) suggested that phytoplankton may contain small rapidly labeled intracellular pools with rapid turnover rates. If this 
rapidly labeled pool is the supply for most of the substrates of respiration as well as excretion, then tracer assimilation should correspond to net growth after several hours (Smith 1982). However, Bidwell's (1977) results show that in exponentially growing phytoplankton recent photosynthate is apparently not a respiratory substrate until after a period of darkness. Peterson (1980) suggested that respiration and excretion processes may be too low relative to net synthesis at fast growth rates to influence tracer estimates very much. This hypothesis was supported by Peterson's (1978) finding of increased overestimation of net production by $\mathrm{C}-14$ assimilation as $\mathrm{P}$-limited growth rates were decreased. The results in Table 1 showed a similar trend of increasing overestimation at the lower growth rates than at the higher growth rates under Nlimitation.

On the other hand, under P-limitation, Harris \& Piccinin (1983), using the double isotope method of Stewart et al. (1971), found that gross photosynthesis was measured by C-14 uptake only at maximum relative growth rates. At low relative growth rates, C-14 uptake approximated net photosynthesis. As previously stated, our results show that the C-14 method estimated net photosynthesis more closely at the higher relative growth rates than at the lower (Table 1). Probably the main difference between the 2 sets of data is due to the variation in the nutrient source in limiting growth rates. For instance, the effects of Plimitation on ATP metabolism results in an alteration in carbon metabolism (i.e. $\mathrm{C}_{3}$ or $\mathrm{C}_{4}$ ) (Harris 1978).

Since respiration of recently assimilated carbon does not apparently start until the dark period (Bidwell 1977) net photosynthesis during the photoperiod will be overestimated by the $\mathrm{C}-14$ method unless $100 \%$ of the respired $\mathrm{C}$ is reassimilated. Dark respiration of recently assimilated $\mathrm{C}-14$ will lead to a more reliable estimate of net PC production. The accuracy of the $\mathrm{C}$ -
14 method in estimating net PC production after a L:D cycle will depend on the specific activity of the respired carbon at night

The results listed in Table 1 indicate that even after $24 \mathrm{~h}$, the $\mathrm{C}-14$ method overestimated net PC production by an average of $16 \pm 19 \%$. On examination of the night-time loss of $\mathrm{C}-14$ from the $\mathrm{PC}$ fraction, it was found that $\mathrm{C}-14$ was being lost from the $\mathrm{PC}$ fraction at a faster rate than the actual decrease in PC concentration. The PC specific activity after $24 \mathrm{~h}$ was an average of $18 \pm 6 \%$ lower than the PC specific activity after $12 \mathrm{~h}$ (Table 4). Calculation of the PC specific activity showed a continuous decrease from the beginning of the dark period ( $12 \mathrm{~h}$ ) to the beginning of the light period ( $24 \mathrm{~h}$; Table 4 ). This gradual but steady drop in PC specific activity at night was remarkably consistent for all species and growth rates. These results suggest that the cells were preferentially respiring recently photoassimilated $C$ (i.e. high specific activity $C$ ) at night as opposed to their pre-existing $C$ pools.

To test whether respiration of high specific activity $C$ could account for the decrease in the specific activity of PC at night, we assumed that the specific activity of the respired $\mathrm{C}\left(\mathrm{SA}_{\mathrm{rc}}\right)$ during the dark period was equal to the photoperiod average specific activity of the inorganic $\mathrm{C}$ (IOC). In all but 2 of the experiments performed $\mathrm{SA}_{\mathrm{rc}}$ was calculated to be not only greater than the PC specific activity but also substantially higher than the daytime average IOC specific activity (Table 4). Such unrealistically larger values of $\mathrm{SA}_{\text {rc }}$ suggest that respiration of recently photoassimilated $C$ cannot entirely account for the apparent decrease in PC specific activity at night. We hypothesized that excretion of DOC during the photoperiod and uptake of low specific activity (DOC) at night was responsible for the decrease in PC specific activity at night. To test this hypothesis, we calculated the DOC excretion and uptake rates that would be required to account for the

Table 4. Specific activities (dpm $\mathrm{mmol}^{-1} \times 10^{6}$ ) of inorganic carbon (IOC) and particulate carbon pools (PC)

\begin{tabular}{|c|c|c|c|c|c|}
\hline Species & $\mu\left(d^{-1}\right)$ & $12 \mathrm{~h} \mathrm{IOC}$ & $12 \mathrm{~h} \mathrm{PC}$ & 24 h PC & $\mathrm{SA}_{\mathrm{rc}}{ }^{\circ}$ \\
\hline P. tricornutum & $\begin{array}{l}0.56 \\
0.25\end{array}$ & $\begin{array}{l}32.9 \\
39.3\end{array}$ & $\begin{array}{l}12.9 \\
13.8\end{array}$ & $\begin{array}{l}11.4 \\
11.7\end{array}$ & $\begin{array}{l}42.6 \\
59.7\end{array}$ \\
\hline P. lutheri & $\begin{array}{l}0.75 \\
0.29\end{array}$ & $\begin{array}{l}33.9 \\
24.6\end{array}$ & $\begin{array}{r}19.7 \\
9.0\end{array}$ & $\begin{array}{r}15.8 \\
7.3\end{array}$ & $\begin{array}{l}68.2 \\
30.3\end{array}$ \\
\hline A. carteri & $\begin{array}{l}0.48 \\
0.20\end{array}$ & $\begin{array}{l}40.3 \\
27.9\end{array}$ & $\begin{array}{r}24.8 \\
9.4\end{array}$ & $\begin{array}{r}19.1 \\
6.4\end{array}$ & $\begin{array}{r}54.6 \\
130.1\end{array}$ \\
\hline Isochrysis sp. & $\begin{array}{l}0.89 \\
0.40\end{array}$ & $\begin{array}{l}31.0 \\
25.9\end{array}$ & $\begin{array}{l}21.1 \\
10.7\end{array}$ & $\begin{array}{r}19.3 \\
8.8\end{array}$ & $\begin{array}{l}28.2 \\
79.4\end{array}$ \\
\hline D. salina & $\begin{array}{l}0.89 \\
0.36\end{array}$ & $\begin{array}{l}54.4 \\
56.9\end{array}$ & $\begin{array}{l}30.0 \\
20.2\end{array}$ & $\begin{array}{l}25.8 \\
17.2\end{array}$ & $\begin{array}{r}211.0 \\
46.1\end{array}$ \\
\hline
\end{tabular}


observed variations in PC specific activity. We discovered that the decline in specific activity could be explained by assuming the respired carbon specific activity to equal the daytime average IOC specific activity, and the DOC taken up in the dark to be supplied by a daytime excretion rate of unlabeled DOC equal to $14.1 \pm 12.6 \%$ of the net photosynthetic rate for the 5 species.

This result seems consistent with the fact that the rate of photosynthesis during the photoperiod calculated from the ${ }^{14} \mathrm{C}$ uptake was greater $(24 \pm 25 \%)$ than the rate implied by the increase in PC (Table 1). The difference between the present overestimation of PC production and the calculated DOC excretion rate is $24-14=10 \%$ of the carbon production rate, a figure which seems quite reasonable as an estimate of respiration when compared to literature values (Humphrey 1975, Pickett 1975, Falkowski \& Owens 1978, Laws \& Wong 1978). It is noteworthy that the overestimation of PC production by ${ }^{14} \mathrm{C}$ was most pronounced at the lower growth rates. Li \& Goldman (1981) recorded similar results of greater C-14 overestimation of $\mathrm{C}$ production at lower growth rates. They also suggested that DOC release could explain these differences. In other words, significant excretion of unlabeled DOC compounds during the photoperiod could account for much of the overestimation of net PC production by the C-14 method. In addition, algal heterotrophy at night amidst a background of low specific activity DOC produced by this process could in part explain the decrease in PC specific activity which we observed at night.

Although net $\mathrm{N}$ and $\mathrm{C}$ assimilation rates were overestimated after $24 \mathrm{~h}$, the $\mathrm{N} / \mathrm{C}$ assimilation ratio averaged $104 \pm 16 \%$ of the actual N/C composition ratio. Thus due to the effects of diel periodicity on $\mathrm{C}$ and $\mathrm{N}$ assimilation, the most accurate estimate of the $\mathrm{N} / \mathrm{C}$ composition ratio was found at the end of the dark cycle. During the photoperiod the N/C assimilation ratio underestimated the N/C composition ratio (Fig. 3) because the specific activity of the protein carbon was less than the specific activity of the total cell C. At night, dark protein synthesis fueled by carbohydrate catabolism, in addition to dark respiration of carbohydrates, caused the protein $\mathrm{C}$ specific activity to become nearly equal to the specific activity of the total cell $C$.

The variability in the $\mathrm{N} / \mathrm{C}$ assimilation ratio during the light-dark cycle is associated with the dark $\mathrm{N}$ uptake capability of the organism. For instance, Paasche et al. (1984) illustrated that groups of dinoflagellates which could take up $\mathrm{N}$ at night had variable $\mathrm{N} / \mathrm{C}$ ratios during the diel cycle. Other groups which could not take up $\mathrm{N}$ at night had a constant $\mathrm{N} / \mathrm{C}$ ratio throughout the light-dark cycle. Amphidinium carteri was found to belong to the former group. Our observations are similar to Paasche et al.'s (1984) results on A. carteri in showing a variable $\mathrm{N} / \mathrm{C}$ ratio throughout the diel cycle.

Estimates of $\mathrm{N} / \mathrm{C}$ composition ratios from N/C assimilation ratios can provide valuable information on the physiological status of natural phytoplankton populations (e.g. Laws et al. 1984, 1985). In $\mathrm{N}$-limited systems, N/C ratios are linearly correlated with growth rate (Laws \& Bannister 1980, Terry 1980, Terry et al. 1985) with $\mathrm{N} / \mathrm{C}$ values approaching the Redfield ratio of 0.15 by atoms (Redfield et al. 1963) at maximum growth rate (Goldman et al. 1979). Thus a population growing slowly under $\mathrm{N}$-limitation will have $\mathrm{N} / \mathrm{C}$ values below the Redfield ratio, with the actual N/C composition ratio being determined by the severity of the $\mathrm{N}$-limitation. At low relative growth rates $\left(\leq 0.1 \mu_{\mathrm{m}}\right)$ the $\mathrm{C} / \mathrm{N}$ ratio in phytoplankton is approximately 20 to 25 (by atoms). High relative growth rates $\left(\geq 0.9 \mu_{\mathrm{m}}\right)$ produce $\mathrm{C} / \mathrm{N}$ composition ratios close to the Redfield ratio of 6.6 by atoms (Goldman 1980). By assuming that the percent protein $\mathrm{C}$ in phytoplankton is approximately equal to 280 times the $\mathrm{N} / \mathrm{C}$ ratio by weight (DiTullio \& Laws 1983), the percent protein is approximately equal to 14.5 and $49 \%$ at relative growth rates approaching 0 and 1 , respectively. Our results yielded $\%$ protein values of $15 \pm 6$ and $46 \pm 6 \%$ at the minimum and maximum growth rates for the 5 species tested (Table 3), and are therefore consistent with the values implied in Goldman (1980).

In conclusion, the percentage of C-14 incorporated into the protein fraction at the end of the light-dark cycle $(24 \mathrm{~h})$ under $\mathrm{N}$-limited conditions allows an accurate estimate of the relative growth rate of a phytoplankton population (Fig. 3). Estimates of $\mathrm{N}$-assimilation from the $24 \mathrm{~h}$ average rates provided an accurate estimate only for relatively fast growth rates. At lower relative growth rates, $\mathrm{N}$-assimilation was significantly overestimated. As a consequence, caution is advised in estimating $\mathrm{N}$-assimilation rates in the field when the $\mathrm{N} / \mathrm{C}$ assimilation ratio implies a low relative growth rate (i.e. $0.4 \mu_{\mathrm{m}}$ ) after a $24 \mathrm{~h}$ light-dark incubation.

\section{LITERATURE CITED}

Barlow, R. G. (1984). Time-series uptake of carbon into photosynthetic products of Benguela phytoplankton populations. J. Plankton Res. 6 (3): 435-442

Bidwell, R. G. S. (1977). Photosynthesis and light and dark respiration in freshwater algae. Can. J. Bot. 55: 809-818

Bligh, E. G., Dyer, W. J. (1959). A rapid method of total lipid extraction and purification. Can. J. Biochem. Physiol. 37: 911-917

Caperon, J., Meyer, J. (1972). Nitrogen-limited growth of marine phytoplankton. Deep Sea Res. 19: 601-632

Cuhel, R. L., Ortner, P. B., Leon, D. R. S. (1984). Night 
synthesis of protein by algae. Limnol. Oceanogr. 29 731-744

DiTullio, G. R., Laws, E. A. (1983). Estimates of phytoplankton $\mathrm{N}$ uptake based on ${ }^{14} \mathrm{CO}_{2}$ incorporation into protein. Limnol. Oceanogr. 28 (1): 177-185

Eppley, R. W., Holmes, R. W., Strickland, J. D. (1967). Sinking rates of marine phytoplankton measured with a fluorometer. J. exp. mar. Biol. Ecol. 1: 191-208

Eppley, R. W., Renger, E. H., Venrick, E. L., Mullin, M. M (1973). A study of plankton dynamics and nutrient cycling in the central gyre of the north Pacific Ocean. Limnol. Oceanogr. 18: 534-551

Falkowski, P. G., Owens, T. G. (1978). Effects of light intensity on photosynthesis and dark respiration in six species of marine phytoplankton. Mar. Biol. 45: 289-295

Folch, J., Lees, M., Stanley, G. H. (1957). A simple method for the isolation and purification of total lipids from animal tissues. J. biol. Chem. 226: 257-266

Glibert, P. M., Lipschultz, F., McCarthy, J. J., Altabet, M. A. (1985). Has the mystery of the vanishing ${ }^{15} \mathrm{~N}$ in isotope dilution experiments been resolved? Limnol. Oceanogr. 30: $444-447$

Goldman, J. C. (1980). Physiological processes, nutrient availability and the concept of relative growth rate in marine phytoplankton ecology. In: Falkowski, P. (ed.) Primary production in the sea. Brookhaven Symp. 31, Plenum Press, New York, p. 179-194

Goldman, J. C., McCarthy, J. J., Peavey, D. G. (1979). Growth rate influence on the chemical composition of phytoplankton in oceanic waters. Nature, Lond. 279: 210-215

Guillard, R. R. L., Ryther, J. H. (1962). Studies of manine planktonic diatoms. I. Cyclotella nana Hustedt and Detonula confervacea (cleve) Gran. Can. J. Microbiol. 8: 229-239

Harris, G. P. (1978). Photosynthesis, productivity and growth: the physiological ecology of phytoplankton. Ergebn. Limnol. 10: 1-171

Harris, G. P., Piccinin, B. B. (1983). Phosphorus limitation and carbon metabolism in a unicellular algae: Interaction beween growth rate and the measurement of net and gross photosynthesis. J. Phycol. 19: 185-192

Harrison, W. G. (1983). Nitrogen in the marine environment: use of isotopes. In: Carpenter, E. J., Capone, D. G. (ed.) Nitrogen in the marine environment. Academic Press, New York, p. 763-809

Huffaker, R. C., Peterson, L. W. (1974). Protein turnover in plants and possible means of its regulation. Ann. Rev. Plant Physiol. 25: 363-392

Humphrey, G. F. (1975). The photosynthesis: respiration ratio of some unicellular marine algae. J. exp. mar. Biol. Ecol. 18: $111-119$

Laws, E. A. (1985). Analytic models of $\mathrm{NH}_{4}^{+}$uptake and regeneration experiments. Limnol. Oceanogr. 30: $1340-1350$

Laws, E. A., Bannister, T. T. (1980). Nutrient- and lightlimited growth of Thalassiosira fluviatilis in continuous culture, with implications for phytoplankton growth in the ocean. Limnol. Oceanogr. 25: 457-473

Laws, E. A., Redalje, D. G., Haas, L. W., Bienfang, P. K. Eppley, R. W., Harrison, W. G., Karl, D. M., Marra, J. (1984). High phytoplankton growth and production rates in oligotrophic Hawaiian coastal waters. Limnol. Oceanogr. 29 (6): 1161-1169

Laws, E. A., Wong, D. C. L. (1978). Studies of carbon and nitrogen metabolism by three marine phytoplankton species in nitrate limited continuous culture. J. Phycol. 14: $406-416$
Li, W. K. W., Goldman, J. C. (1981). Problems in estimating growth rates of marine phytoplankton from short term ${ }^{14} \mathrm{C}$ assays. Microb. Ecol. 7: 113-121

Li, W K. W., Glover, H. E., Morris, I. (1980). Physiology of carbon photoassimilation by Oscillatoria thiebautii in the Caribbean Sea. Limnol. Oceanogr. 25 (3): 447-456

Macisaac, J. J., Dugdale, R. C. (1972). Interactions of light and inorganic nitrogen in controlling nitrogen uptake in the sea. Deep Sea Res. 19: 209-232

Marchesi, S. L., Kennell, D. (1967). Magnesium starvation of Aerobacter aerogenes. III. Protein metabolism. J. Bacteriol. 93: 357-366

Morris, I., Skea, W. (1978). Products of photosynthesis in natural populations of marine phytoplankton from the Gulf of Maine. Mar. Biol. 47: 303-312

Morris, 1., Glover, H. E., Yentsch, C. S. (1974). Products of photosynthesis by marine phytoplankton: the effect of environmental factors on the relative rates of protein synthesis. Mar. Biol. 27: 1-9

Paasche, E., Bryceson, I., Tangen, K. (1984). Interspecific variation in dark nitrogen uptake by dinoflagellates. J. Phycol. 20: 394-401

Perry, M. J. (1976). Phosphate utilization by an oceanic diatom in phosphorus-limited chemostat culture and in the oligotrophic waters of the central North Pacific Ocean. Limnol. Oceanogr 21: 88-107

Peterson, B. J. (1978). Radiocarbon uptake: Its relation to net particulate carbon production. Limnol. Oceanogr. 23 (1): 179-184

Peterson, B. J. (1980). Aquatic primary productivity and the ${ }^{14} \mathrm{C}-\mathrm{CO}_{2}$ method: A history of the productivity problem. Ann. Rev. Ecol. Syst. 11: 359-385

Pickett, J. M. (1975). Growth of Chlorella in a nitrate-limited chemostat. Pl. Physiol. 55: 223-225

Pine, M. J. (1972). Turnover of intracellular proteins. Ann. Rev. Microbiol. 26: 103-126

Redalje, D. (1980). The effects of environmental factors on the general patterns of carbon metabolism for marine phytoplankton. Ph.D. thesis, Univ. Hawaii

Redfield, A. C., Ketchum, B. H., Richards, F. A. (1963). The influence of organisms on the composition of seawater. In: Hill, M. N. (ed.) The sea, Vol. II. Interscience, New York, p. 26-77

Sakshaug, E., Holm-Hansen, O. (1977). Chemical composition of Skeletonema costatum and Pavlova lutheri as a function of nitrate-, phosphate-, and iron-linited growth. J. exp. mar Biol. Ecol. 29: 1-34

Slawyk, G., Collos, Y., Minas, M., Grall, J. R. (1978). On the relationship between carbon-to-nitrogen composition ratios of the particulate matter and growth rate of marine phytoplankton from the northwest African upwelling area. J. exp. mar. Biol. Ecol. 33: 119-131

Smith, R. E. H. (1982). The estimation of phytoplankton production and excretion by Carbon-14. Mar. Biol. Lett. 3: 325-334

Stewart, F. C., Craven, G. H., Weerasinghe, P. R., Bidwell, R. G. S. (1971). Effects of prior environmental conditions on the subsequent uptake and release of carbon dioxide in the light. Can. J. Bot. 49: 1999-2006

Strickland, J. D. H., Parsons, T. R. (1968). A practical handbook of seawater analysis. Bull. Fish. Res. Bd Can. 167

Terry, K. L. (1980). Nitrogen and phosphorus requirements of Pavlova lutheri in continuous culture. Botanica Mar. 13: $757-764$

Terry, K. L., Hirata, J., Laws, E. A. (1985). Light-, nitrogen-, and phosphorus-limited growth of Phaeodactylum tricornutum Bohlin Strain TFX-1: chemical composition, carbon 
partitioning, and the diel periodicity of physiological processes. J. exp. mar. Biol. Ecol. 86: 85-100

Thacker, A., Syrett, P. J. (1972). The assimilation of nitrate and ammonium by Chlamydomonas reinhardii. New Phytol. $71: 423-433$
Wheeler, P. A., Olsen, R. J., Chisolm, S. W. (1983). Effects of photocycles and periodic ammonium supply on three marine phytoplankton species. II. Ammonium uptake and assimilation. J. Phycol. 19: 528-533

This article was submitted to the editor; it was accepted for printing on June 25, 1986 